\title{
O uso da categoria "raça" na biomedicina
}

\section{The use of the category "race" in biomedicine}

\author{
Silvia Cardoso Bittencourt ${ }^{1}$ \\ Sandra Caponi ${ }^{2}$
}

\section{RESUMO}

O propósito deste estudo é analisar o conceito de "raça" na biomedicina a partir das reflexões de Hannah Arendt, Richard Lewontin e Marshall Sahlins. O uso da categoria "raça", geralmente, tem gerado discussões epistemológicas em várias áreas do conhecimento, pois carrega aspectos políticos e ideológicos nem sempre explícitos. Assim, a partir de exemplos de utilização de "raça" na área biomédica, questiona-se seu uso enquanto categoria de análise. Um efeito indesejável ao admitir características biológicas inatas é que fatores relacionados ao modo de vida e ao contexto ao qual o indivíduo pertence podem ser negligenciados. Portanto, conclui-se que associar condições de aptidão, saúde ou propensão a determinada conduta com "raça" como categoria biológica, desvia o olhar de aspectos históricos, condições sócio-econômicas e discriminação cultural, podendo levar à defesa de posições ideológicas próximas ao determinismo biológico.

Palavras-chave: Determinismo biológico. Raça. Biomedicina. Racismo. Etnicidade. Ideologia.

\section{ABSTRACT}

The purpose of this article is to analyze the concept of race in biomedicine by theoretical reflections of Hannah Arendt, Richard Lewontin and Marshall Sahlins. The use of the category "race" usually has generated epistemological discussions in several areas of knowledge, because it carries political and ideological not always explicit. Thus, as examples of the use of race in the biomedical area, we question its use as a category of analysis. One undesirable characteristics to admit is that innate biological factors related to lifestyle and the context to which the individual belongs can be neglected. Therefore, it follows that attach conditions of fitness, health, or prone to certain conduct with race as a biological category, look away from the historical, socioeconomic and cultural discrimination, which may lead to defend positions close to the ideological determinism biological.

Key words: Biological determinism. Race. Biomedicine. Racism. Ethnicity. Ideology.

\footnotetext{
${ }^{1}$ Doutoranda do Programa de Pós-Graduação Interdisciplinar em Ciências Humanas. scbflor@hotmail.com

${ }^{2}$ Professora do Departamento de SAúde Pública e do Programa de Pós-Graduação Interdisciplinar em Ciências Humanas. sandracaponi@newsite.com.br
} 


\section{INTRODUÇÃO}

"O que nos interessa especialmente, porém, é que, no horizonte biopolítico que caracteriza a modernidade, o médico e o cientista movem-se naquela terra de ninguém onde, outrora, somente o soberano podia penetrar." (AGAMBEM, 2002, p.166)

Poderíamos citar vários exemplos em que a prática biomédica tem alcançado êxito, justificando a sua manutenção como prática social. Por outro lado, tem sido questionada por diversos segmentos da sociedade (de grupos leigos a profissionais de diferentes áreas) a extrapolação de determinadas "verdades" baseadas em conhecimentos supostamente científicos para problemas que o ser humano enfrenta e que não estão vinculados apenas à sua biologia. Ou ainda, que podem se manifestar no corpo biológico, mas cujas origens não estão neste último, e sim na forma como estamos vivendo enquanto sujeitos inseridos em determinada sociedade. Mais do que isso, alguns conceitos divulgados na prática biomédica como "verdades" por pretenderem ser baseados em critérios das ciências biológicas e biomédicas são reflexo da ideologia de determinados cientistas. Um desses conceitos que se estabeleceram como uma verdade científica é o conceito de "raça".

O propósito deste estudo é analisar o conceito de "raça" a partir das reflexões de Hannah Arendt $(1989)^{3}$, Richard Lewontin $(2003,2006)$ e Marshall Sahlins (1976, 1997), e de três exemplos de situações em que esse conceito é utilizado na área biomédica. A categoria "raça" continua sendo utilizada em pesquisas nessa área e, em consequência, mantém-se como um critério para a conduta médica e o delineamento de políticas públicas para alguns problemas de saúde. Como exemplos, serão utilizados os casos da anemia falciforme em negros (FRY, 2005b; LEWONTIN, 2006), a refratariedade da ação de medicamentos anti-hipertensivos para a "raça" negra como justificativa para o desenvolvimento de drogas para tratar Hipertensão Arterial Sistêmica (HAS) específicas para esse grupo (COOPER; KAUFMAN; WARD, 2003; KAUFMAN, 2006, 2008; LAGUARDIA, 2007) e a busca de genes relacionados ao Diabetes Mellitus Não Dependente de Insulina (DMNID) em determinados grupos

\footnotetext{
${ }^{3}$ Esta autora considera raça uma categoria ligada à ideologia do racismo, e não uma categoria biológica baseada em critérios científicos.
} 
étnicos, como os aborígenes australianos (MCDERMOTT, 1998), caracterizando-os como uma "raça" com maior tendência a desenvolver essa doença.

\section{2. "RAÇA": CONCEITO NÃO CIENTÍFICO UTILIZADO COMO CATEGORIA MÉDICA}

Na prática, parece ser impossível usar o conceito de "raça" sem que este esteja carregado de racismo, até mesmo quando não se pretende ser racista, como, por exemplo, quando se pretende utilizar o termo "apenas para fazer ciência". Embora se fale em "raça" como constatação de características biológicas de um grupo com ancestralidade e procedência geográfica comuns, ou seja, algo natural e objetivo, e por isso com pretensão de neutralidade, é difícil que esse termo não esteja impregnado de juízos de valor, uma característica subjetiva.

Raj Bhopal (2004) desenvolve um glossário de termos relacionados às categorias "raça" e etnicidade em trabalhos epidemiológicos, área em que essa categoria é muito utilizada. Esse autor - a exemplo também de L. Hunt e M. Megyesi (2008) - destaca que àqueles termos são utilizados muitas vezes de forma indistinta, e que tal conduta pode gerar confusão e resultados improdutivos. Muitas vezes, na tentativa de não utilizar o termo "raça", utiliza-se o termo "etnicidade", de uma forma "conjugada" ou apenas substituindo o primeiro termo, mas ainda com o significado de um determinismo biológico em relação a grupos humanos (BOPHAL, 2004; HUNT; MEGYESI, 2008).

Levando em conta sua experiência, Bhopal (2004), que se identifica como "um Punjabi nascido indiano e criado na Escócia", tenta definir "raça" e etnicidade no desenvolvimento de pesquisas na área biomédica. Para ele, o termo "raça", quando utilizado nos estudos epidemiológicos do Reino Unido tem o seguinte significado:

Por um uso histórico e comum, o grupo (subespécies no sentido do uso científico tradicional) a que uma pessoa pertence como resultado de uma mistura de características físicas, tais como cor da pele e textura do cabelo, os quais refletem ancestralidade e origem geográfica, tal como identificadas por outros ou autoidentificadas. A importância de fatores sociais na criação e perpetuação de categorias raciais tem feito com que se coloque o conceito de forma ampliada, incluindo uma herança social e política comuns, tornando seu uso similar ao do termo etnicidade. Raça e etnicidade têm sido utilizadas como 
sinônimos, causando confusão e gerando um termo híbrido - raça/etnicidade (BHOPAL, 2004, p.444).

O termo "Etnicidade", por sua vez, é definida como:

O grupo social ao qual a pessoa pertence e com o qual se identifica ou é identificado por outros, como resultado de uma mistura de fatores culturais e outros fatores, incluindo a linguagem, dieta, religião, ancestralidade e características físicas associadas com raça. Além disso, o conceito (de etnicidade) tem sido utilizado como sinônimo de raça, mas este é um uso mais prático do que científico (BOPHAL, 2004, p.443).

O uso "científico" do termo "raça", baseado em aspectos biológicos, como sinônimo de uma "subespécie" foi defendido durante os séculos XVIII e XIX, e após as atrocidades da Segunda Guerra Mundial, no século passado, foram realizados esforços para que o aspecto de cientificidade fosse deixado de lado. No entanto, parece difícil que tenhamos nos desvencilhado desse aspecto da "raça" como sinônimo de uma subespécie do Homo sapiens.

A ideia de que algumas dessas "subespécies" são melhores do que outras, e que, por esse motivo, teriam mais direito à vida, é o que move o racismo. No século $\mathrm{XVIII}$, o pensamento racista era mais uma entre outras ideias expressas, mas, segundo Hannah Arendt (1989), conseguiu se firmar e tornar-se uma "ideologia plenamente desenvolvida". A autora destaca a diferença entre simples ideias e ideologias, estas últimas consideradas como:

[...] sistemas baseados numa única opinião suficientemente forte para atrair e persuadir um grupo de pessoas e bastante ampla para orientá-las nas experiências e situações da vida moderna. Pois a ideologia difere da opinião na medida em que se pretende detentora da chave da história e em que julga poder apresentar a solução dos 'enigmas do universo' e dominar o conhecimento íntimo das leis universais 'ocultas' que supostamente regem a natureza e o homem (ARENDT, 1989, p.189).

Sua força de persuasão está relacionada a efeitos imediatos e a aspectos políticos, e não a aspectos científicos ou históricos, como pretendem cientistas e historiadores. $O$ fato de aspectos científicos serem apresentados em relação ao racismo tem a ver com o fato de alguns cientistas partilharem dessa doutrina e buscarem argumentos para defendê-la. Segundo ela, "a culpa não é da ciência em si, 
mas de certos cientistas não menos hipnotizados pelas ideologias que seus concidadãos menos cultos" (ARENDT, 1989, p.189).

O "gene" do racismo, tal como se apresenta com seus resquícios até os dias de hoje, ainda de acordo com Arendt (1989), surge na França no século XVIII, com o Conde de Boulainvilliers, defensor da França como possuidora de duas nações, uma de origem germânica — os nobres que conquistaram os habitantes antigos — e os gauleses (dos quais descendia o povo). Os segundos deveriam obedecer aos primeiros, pois estes eram os "mais fortes", e Boulainvilliers "baseava sua doutrina exclusivamente no eterno direito da conquista" (ARENDT, 1989, p.192). O Conde estava preocupado com o poder do Terceiro Estado ${ }^{4}$ e insatisfeito com o rei da França, este último interessado em representar a nação como um todo, e não apenas a nobreza. Boulainvilliers apreciava as ideias políticas de Spinoza, e ao transformar força em conquista, tornou esta última um direito natural, ou seja, um privilégio inato. Considerava superior "o povo que conquista", e plantou a semente da guerra civil ao inventar dois povos.

Após a Revolução, a nobreza francesa procurou refúgio na Alemanha e na Inglaterra, e as ideias de Boulainvilliers mostraram-se úteis enquanto arma política. Falava-se em uma "aristocracia internacional", em uma federação dos nobres germânicos, incluindo os nobres franceses (ARENDT, 1989). Outra ideia, não baseada apenas na conquista (pois os nobres franceses haviam sido derrotados), passa a ser defendida, desprezando "o povo que veio dos escravos, uma mistura de raças", e a nobreza da França "descobre pertencer a outra origem genealógica", uma raça ligada a uma "casta internacional".

A fixação acerca da "superioridade germânica" foi primeiro cultivada na França. No século XIX, Augustin Thierry distingue a "nobreza germânica" da "burguesia celta" (ARENDT, 1989) e Gobienau", em 1853, publica o "Essai sur l'inegalité dês raices

\footnotetext{
${ }^{4}$ Sob o Antigo Regime da França, a população era dividida em três ordens na assembléia representativa convocada pelo príncipe: o Clero, a Nobreza e o Terceiro Estado, ordem que abrigava representantes do povo e da burguesia. Essa divisão permaneceu até a Revolução Francesa (LEFEVRE, 1989).

${ }^{5}$ Segundo Hanna Arendt (1989), "Embora, em termos nobiliárquicos, Gobineau fosse possivelmente um impostor (seu título francês é mais do que duvidoso), exagerava e levava além dos limites as doutrinas genealógicas, expondo-as ao ridículo quando afirmava descender, por intermédio de um pirata escandinavo, do deus germânico Odim, e gabava-se por 'também pertencer à raça dos deuses'". (p. 202)
} 
humaines" (ARENDT, 1989; COMAS, 1950). Essa obra traz a superioridade da "raça germânica", também chamada ariana, sobre as outras e, em conjunto com as ideias do romantismo, "com uma crença fundamental da personalidade como fim único", de acordo com a autora, estabelece-se a ideologia racista de uma forma bem desenvolvida.

Como um dos esforços no sentido de combater a "cientificidade da raça", a UNESCO $^{6}$ lança, logo após a Segunda Guerra, uma série de textos chamada $A$ questão racial diante da ciência moderna. No texto de Juan Comas (1950), que faz parte dessa série, o autor faz uma retrospectiva das primeiras referências sobre juízos de valor em relação a grupos com características "superiores" a partir de sua ancestralidade e de características físicas. Ele se refere a uma gravação egípcia (cerca de 1800 anos a.C.) que determinava que os negros não poderiam ultrapassar certo limite do território e destaca que essa era uma medida política, pois para vender produtos era permitido o acesso dos negros. Cita também o Antigo Testamento, que fala da superioridade de um povo em relação a outro a partir de sua genealogia biológica. Por outro lado, no Novo Testamento, um livro de referência em relação a valores na sociedade ocidental, Comas identifica outra abordagem, reproduzindo uma mensagem dos Atos dos Apóstolos que diz: "Ele há feito nascer do mesmo sangue a todo gênero humano que povoará a extensão da terra" (COMAS, 1950).

Não parece ser essa a forma de pensar sobre o "sangue" dos adeptos do racismo. Desde Gobineau, a "mistura de raças" seria responsável pela degeneração da humanidade, levando ao desaparecimento do homem. Tal mistura ocorreria através do "sangue", símbolo que caracteriza indivíduos pertencentes a um mesmo grupo familiar. Acontece que "sangue" não era utilizado apenas como uma categoria simbólica. Havia a crença "científica" em uma mistura de sangue, e Comas (1950) inclusive dá o exemplo da transfusão de sangue entre pessoas de "raças" diferentes, como um argumento para desmistificar esse "dado científico" utilizado pelos racistas. Na época em que foi utilizada essa argumentação, ainda estávamos sob a influência das

${ }^{6}$ UNESCO - Organização das Nações Unidas para a Educação, a Ciência e a Cultura.

Cad. de Pesq. Interdisc. em Ci-s. Hum-s., Florianópolis, v.10, n.97, p. 290-311, jul./dez. 2009 
"comprovações científicas", estudos que avaliavam o tamanho e a forma dos crânios para caracterizar quem pertencia a "raças superiores".

A "antropossociologia" e a "teoria da seleção social", desenvolvidas na França e na Alemanha a partir do final do século XIX, eram apoiadas em investigações estatísticas (COMAS, 1950) e, embora não tenham conseguido provar suas teorias, influenciaram o conceito do que até os dias de hoje se entende por "raça".

No decorrer do século $\mathrm{XX}$, outras estratégias se desenvolveram para manter a ideia de segregação. Otto Klineberg (1951) discorre sobre os testes psicológicos que encontram "superioridade" de inteligência em brancos americanos e europeus quando comparados com indígenas americanos ou outros grupos étnicos. O autor destaca a importância dos aspectos culturais, que levam a outras formas de olhar o mundo sem que isso signifique uma inteligência diminuída. Essa última é considerada inata pelos adeptos do racismo ao analisarem o resultado dos testes em pessoas de outros continentes com características físicas diferentes.

A tentativa de tornar científica a tese de que possuímos características inatas em nossa biologia determinando nossas condutas enquanto sociedade continua no século XX. Autores como Lewontin (2003) e Sahlins (1976), discorrem sobre as implicações da sociobiologia, que volta a falar em determinismo biológico na década de 1970. Aqui a diferença entre os indivíduos também está nos genes: são eles que podem explicar este ou aquele comportamento. Sahlins (1976) argumenta que:

[A] sociobiologia muda a integridade da cultura como algo por si só, como uma criação humana simbólica e distintiva. No lugar de uma constituição social de significados, oferece a determinação biológica das interações humanas com a fonte primária na propensão evolucionária individual de genótipos para maximizar seu sucesso reprodutivo (SAHLINS, 1976, p.20).

O discurso muda, pois não podemos falar em qualidades inatas apenas pelas características fenotípicas. Como justificar que uma pessoa de pele branca com pais de pele negra tenha características diferentes de uma pessoa branca com pais de pele branca? Tem que estar no genótipo a diferença, assinalada em seu código genético.

Para Lewontin (2003), por sua vez,

O determinismo biológico (biologismo) tem sido um poderoso meio para explicar as dificuldades de status, riqueza e poder observadas nas sociedades 
capitalistas industriais contemporâneas e definir os 'universais' humanos de comportamento como características naturais dessas sociedades. (...) se essas desigualdades são determinadas biologicamente, então são inevitáveis e imutáveis. (LEWONTIN, 2003, p.18)

O foco passa a ser o indivíduo e seus descendentes "mais aptos", no caso, e não por acaso, tomados como categoria de referência na maioria dos estudos atuais, os descendentes de europeus, e agora também os norte-americanos, com pele branca. A cor da pele é uma diferença que altera minimamente o código genético quando comparamos o genoma de alguém com pele branca com outro de alguém de pele não branca. A quantidade e o tipo de melanina que ocorrem na derme têm a regulação controlada por apenas quatro a seis genes, dentre os 25 mil estimados no nosso genoma (PENA, 2005).

Sahlins (1976) sugere, a partir da análise de estudos etnográficos, que mesmo em populações "isoladas", os membros de uma determinada comunidade têm sua linhagem genética dependendo de grupos externos. Isso ocorre em função das trocas entre os grupos, e são considerados membros da família indivíduos que têm origem em outros grupos étnicos e que não compartilham da mesma origem "familiar", no sentido de ascendência em relação aos genitores. A partir do momento em que integram a nova "família", no sentido étnico, passam a fazer parte da família no sentido anterior, genealógico.

Se essa "troca" de genes já acontecia antes e se considerarmos que cada vez as populações estão menos isoladas, é possível que nossos genes sejam uma "mistura" que provém de indivíduos com características físicas diferentes. Em termos étnicos, no sentido de compartilhar uma determinada cultura, ainda podemos falar em etnias diversas, mas cada vez mais sofrendo intercâmbio e formando novos "modos" de lidar com a vida em sociedade.

Sobre modos subjetivos relacionados a diferentes culturas, embora alguns considerem que as minorias vêm sendo englobadas pelo modo de vida do povo ocidental dominante, podemos pensar que, apesar da tentativa de manter uma sociedade que privilegie determinadas características sociais, culturais e econômicas, outras formas de ver o mundo não estão extintas. As subjetividades se intercambiam e 
se fazem aparentes em novos e velhos contextos geográficos, mesmo que de formas não dominantes (FRY, 2005a; SAHLINS, 1997).

Ao pensarmos em intercâmbio de "genes" e de subjetividades, não é possível negar a base biológica que nos confere características biológicas únicas, que cada indivíduo possui. O que não parece ser válido é considerar que características desenvolvidas pela natureza para nos sairmos melhor em determinados contextos geográficos, como a cor da pele, possam servir para "determinar" tantas outras reações, biológicas ou de comportamento.

\section{3. "RAÇA" E DETERMINISMO BIOLÓGICO}

Giorgio Agamben (2002), ao abordar a questão da biopolítica (o poder sobre a vida) e da naturalização das relações políticas, destaca que os princípios da nova biopolítica, surgida na época das ações alemãs da Segunda Guerra, "são ditados pela eugenética, compreendida como a ciência da hereditariedade genética de um povo" (p.152). O poder de polícia exercido pela medicina como novo campo de atuação política tem a "raça" como um critério para intervir no corpo da população (AGAMBEN, 2002). Em obra escrita por Ottomar Vershuer ${ }^{7}$ e Eugen Fisher ${ }^{8}$ refere que: "A raça não é determinada pela combinação desta ou daquela característica que seja possível mensurar, por exemplo, com uma escala de cores [...]. A raça é herança genética e nada mais que a herança" (VERSHUER, 1942 apud AGAMBEN, 2002, p.153). Agamben (2002, p.154) diz ainda que "tanto Fischer quanto Verschuer sabem, porém, que uma raça pura, no sentido dessa definição, é praticamente impossível de identificar

\footnotetext{
7 Ottmar Verschuer (1896-1969), biologista e eugenista, diretor do Instituto de Antropologia Hereditariedade Humana e Eugenia do Instituto de Biologia Genética e Higiene Racial. Seu envolvimento direto com os crimes de guerra não conseguiu ser provado (há indícios, mas as provas de seu envolvimento foram eliminadas), embora pareça claro que não só ele estava ciente dos experimentos com cobaias humanas realizados em Ausschwitz, como colaborava com os mesmos. Ainda assim, depois da Guerra, continuou atuando como renomado "geneticista" na Alemanha Ocidental (WIKIPEDIA, 2007a).

${ }^{8}$ Eugen Fischer (1874-1967), professor de medicina, antropologia e eugenia. Foi um dos responsáveis pelas teorias científicas germânicas nazistas de Higiene Racial. Durante o Regime nazista desenvolveu as especificações fisiológicas utilizadas para determinar as origens raciais. Ele e sua equipe fizeram experimentos com ciganos e alemães de origem africana, com amostras de sangue e medidas cranianas para validar cientificamente suas teorias (grifo meu) (WIKIPEDIA, 2007b).
} 
(em particular, nem os hebreus nem os alemães [...] constituem num sentido próprio uma raça)". Lembra ainda, que as primeiras leis expedidas pelo regime nacionalsocialista estão relacionadas à eugenética ${ }^{9}$. O autor destaca que não é possível entender o sentido e a rapidez dessas leis se pensarmos apenas no sentido eugenético: é decisivo seu caráter político. Argumentos de cientistas, como um professor de química médica da universidade de Frankfurt, segundo Agamben (2002) "não suspeito de simpatia pelo regime nazista", que testemunhou diante de um tribunal afirmando que "do ponto de vista científico, a preparação desses experimentos havia sido esplêndida"10 (AGAMBEN, 2002, p.163), parecem refletir a ideia de que a ciência é algo neutro e isento de outras influências que não apenas o "saber científico objetivo".

Richard Cooper, Jay Kaufman e Ryk Ward (2003), ao falarem sobre ao uso da "raça" enquanto categoria científica, destacam que, apesar de não ser possível negar a variabilidade genética e a diversidade biológica entre populações, não se pode inferir que tais diferenças estejam relacionadas a categorias raciais, ou que "raça" seja um sistema efetivo para sumarizar essas variações. O uso do mapeamento genético para identificar variações genômicas relacionadas a problemas de saúde ${ }^{11}$ e suas soluções, associando essas descobertas à categoria "raça", lembra as grandes promessas científicas do século XX: pesquisas que nos prometeram descobrir "chaves para enigmas do universo" e, ao final, as suas consequências práticas não tão benéficas. Sob esse aspecto, associar as descobertas da genômica à "raça" não seria, segundo os autores, "um bom começo de jornada". Isto porque, a plasticidade desse conceito, impregnado de usos pouco nobres, pode tanto incluir pesquisas com o intuito de buscar soluções para melhorar a saúde como servir para fins eugênicos e de discriminação de subgrupos populacionais.

Sobre a concordância entre o fenótipo, que incluiria as características utilizadas habitualmente para classificar uma "raça", e o genótipo do indivíduo em questão, Sérgio

\footnotetext{
${ }^{9}$ Leis relacionadas à esterilização de pessoas com doenças crônicas e à proibição de casamentos entre pessoas doentes.

${ }_{11}^{10}$ Referindo-se aqui aos experimentos com cobaias humanas.

11 Tem havido uma grande polêmica no meio científico sobre a validade de estudos que avaliam a resposta farmacológica para anti-hipertensivos em indivíduos de origem africana nos Estados Unidos. Como consequência dessas pesquisas, foi lançado um medicamento direcionado a indivíduos negros, sob o argumento de que outros medicamentos, anteriormente utilizados, não estavam sendo eficazes.
} 
Pena (2005), em estudo realizado no Brasil, não encontrou correlação importante entre ambos. Cerca de um terço dos indivíduos da sua pesquisa que se autodefiniram e foram definidos como da "raça branca" apresentaram ancestralidade africana em seu genótipo, e cerca de um terço dos indivíduos classificados como "pretos e pardos" (autodefinidos e definidos por dois observadores) apresentaram cerca de um terço de ancestralidade européia. Para esse autor, no Brasil, o fato de um médico considerar a cor da pele como um dado para inferir doenças como a anemia falciforme ${ }^{12}$ vai ser menos benéfico do que, possivelmente, induzir a um erro.

Um dado interessante, obtido a partir de estudos realizados com populações intercontinentais e que tem a concordância da maior parte dos geneticistas, é o de que 90 a $95 \%$ da variabilidade genética ocorrem entre pessoas de um mesmo continente, sendo discordante da ideia de "raça" (COOPER; KAUFMAN; WARD, 2003; LEWONTIN, 2006; PENA, 2005). Estudos comparando a variabilidade genética de pessoas em continentes diferentes, entre pessoas das chamadas "raças" diferentes, mostram apenas 5 a $10 \%$ de variabilidade (LEWONTIN, 2006; PENA, 2005).

Quando são realizados estudos que buscam relações causais - e estudos epidemiológicos que incluem "raça" como uma das variáveis e pretendem estabelecer relações de causa e efeito relacionadas a essa categoria - é preciso que se tenha em mente que, na maioria das vezes, a etiologia do agravo estudado permanece desconhecida. Ocorre uma inferência de que o mecanismo causal está na associação, mesmo que não se saiba qual é esse mecanismo (BHOPAL, 1997). Pode-se perceber em determinado estudo que entre mulheres negras a fertilidade é maior e inferir, por exemplo, que essa seja uma característica da "raça" negra.

Por outro lado, ao investigarmos mais, podemos relacionar a maior fertilidade a outros fatores. Por exemplo, desconhecimento de métodos contraceptivos por falta de informação, quer seja por essas mulheres não frequentarem serviços de saúde ou por

\footnotetext{
${ }^{12}$ Sérgio Pena (2005) destaca que a anemia falciforme, que aparece em indivíduos homozigotos para um determinado gene, "não é uma doença de negros, nem uma doença africana, e sim uma doença eminentemente geográfica, produto de uma bem sucedida estratégia evolucionária humana para lidar com a malária causada pelo Plasmodium falciparum". Essa alteração genética tem cinco subtipos, quatro encontrados em sub-regiões africanas e um quinto que ocorre na Ásia Menor e na Índia, o que significa que muitas regiões da África não possuem comunidades populacionais com essa mutação, apenas pessoas negras que têm origem nessas quatro regiões.
} 
não entenderem a língua do país onde estão morando e não apreenderem as explicações que lhes estão sendo dadas ou em função de suas crenças sobre uso de determinados métodos. Pode haver ainda, outros fatores causando viéses ou confusão dos resultados, como a renda familiar e a classe social, que não tenham sido levados em conta na pesquisa.

Sobre esse aspecto, Josué Laguardia (2007), ao analisar o uso da categoria raça em estudos epidemiológicos, destaca que outras causas têm sido ignoradas na gênese das doenças, privilegiando a causa genética, e que:

[...] pressupostos biológicos e comportamentalistas ressaltam o caráter ideológico dos marcos teórico-conceituais que originam e legitimam os seus achados científicos, baseados em uma visão do corpo biológico descolado de seu contexto sócio-cultural, econômico e político específico. (LAGUARDIA, 2007, p.259)

Quando se fala em relações causais, de acordo com Anne Fagot-Largeault (2006), há de se considerar, em primeiro lugar, que "tudo não é ligado a tudo": há de se excluir que determinado efeito não esteja relacionado a outras causas; em segundo lugar, há de se considerar uma ordem temporal: o efeito não pode preceder a causa; e, em terceiro, há de se buscar o "mecanismo" pelo qual causa e efeito estejam relacionados, pois apenas dados estatísticos não nos garantem essa relação. Na busca de explicação para um mecanismo, identifica-se uma "sequência causal intermediária", e não apenas uma causa que leva a determinado efeito.

Para essa autora, essa sequência algumas vezes pode ser parcialmente especulativa, baseada em conhecimentos fora do domínio considerado, ou seja, sofre influência de outros saberes. Se não conhecemos bem uma "sequência causal intermediária" e produzimos certas especulações, ainda assim esses dados podem ser divulgados como resultados científicos e levar a erros de interpretação, quando embutidos em determinados conceitos ou "verdades". Essas verdades podem se tornar rótulos, classificações que se propagam nos meios profissionais ou leigos. Como habitualmente nossa postura enquanto cientistas é etnocêntrica, os grupos a quem delegamos certas características passam a interagir de acordo com os conceitos que atribuímos a eles, ou, pelo menos, nós passamos a agir a partir de nossos conceitos atribuídos a eles. 
lan Hacking (2006) destaca que o processo de classificação implica em interações entre as classificações e o indivíduo classificado. Tomando o caso do autismo como exemplo, ele aponta para as diferentes classificações que as pessoas enquadradas nesse grupo sofreram ao longo do uso desse termo, desde a sua primeira utilização no início do século XX. O nome dado a um indivíduo modifica seu comportamento por lhe imprimir esta ou aquela característica esperada, de acordo com os especialistas responsáveis pela categorização. A modificação ocorre por um feedback positivo, quando o indivíduo classificado reforça as características que the são delegadas, ou negativo, quando esse indivíduo discorda e luta para mostrar que não é portador somente daquelas características. E ainda mais: a própria classificação sofre interação com o grupo classificado, na medida em que releituras são feitas pelos cientistas a respeito do mesmo.

No caso dos autistas, o fato de frequentarem instituições, de serem submetidos a rotinas a partir das teorias formuladas a seu respeito e de conviverem com outras crianças consideradas "anormais", torna-os cada vez mais "autistas". A classificação deixa de ser apenas científica para se tornar também administrativa, ou seja, passa a determinar a forma como a sociedade vai lidar com esses indivíduos. A interação entre a classificação e o indivíduo, segundo o autor, reforça a própria categorização, e não sabemos se esses indivíduos viveriam melhor ou pior se não fossem assim classificados.

\section{4. "RAÇA" E BIOMEDICINA: OS EXEMPLOS DA ANEMIA FALCIFORME, DA HIPERTENSÃO ARTERIAL SISTÊMICA E DO DMNID}

Quando insistimos em utilizar "raça" como categoria, incluindo apenas mais uma variável para tentar estabelecer relações causais, também corremos o risco de categorizar pessoas e de lhes direcionar certa forma de posicionamento na sociedade. Atualmente, alguns cientistas, mesmo tentando utilizar o termo desvencilhando-o do racismo, quer seja utilizando o termo "raça" ou optando por "etnicidade" como uma categoria que classifica grupos étnicos com determinadas categorias biológicas que os 
diferenciam de outros, acabam reforçando uma visão que leva em conta o conceito de subespécies humanas.

É na área médica que o racismo pode estar se mantendo enquanto ideologia, e para exemplificar essa questão serão utilizados três exemplos: (1) o da anemia/traço falciforme como uma doença de negros, (2) a Hipertensão Arterial Sistêmica (HAS) e o desenvolvimento de medicamentos anti-hipertensivos para negros e (3) a busca de genes responsáveis pelo diabetes em determinadas etnias, como a dos aborígines na Austrália.

A anemia falciforme, doença que tem sido relacionada a negros ou afrodescendentes, ocorre quando uma pessoa possui os genes mutantes da hemoglobina, que acabam por lhe conferir uma forma anômala, levando a determinados sintomas. Para ocorrer a doença, é necessário que aconteça a homozigose, pois essa mutação no gene é recessiva e desenvolveu-se provavelmente como uma forma de proteção contra o agente infeccioso da malária. O traço falciforme que ocorre na heterozigose confere proteção a essa infecção, e provavelmente a mutação ocorreu como uma adaptação em áreas em que a malária era frequente.

Embora cientificamente saiba-se que essa não é uma doença/característica genética (no caso do traço falciforme) apenas de negros ou afro-descendentes, tem-se utilizado o argumento de que ela ocorre principalmente nesses indivíduos e direcionado políticas públicas para esse agravo. Essa seria uma forma de "compensar" uma falta de assistência a essa população, inclusive utilizada por ativistas negros para reafirmar uma identidade étnica (FRY, 2005b; MAIO; MONTEIRO, 2005).

Mesmo quando não se afirma que a anemia/traço falciforme são encontrados apenas em negros/afro-descendentes, acaba ocorrendo um direcionamento para esses grupos (DINIZ; GUEDES, 2006). Esse direcionamento pode ser algo deletério, tanto na área médica ${ }^{13}$ como social e politicamente, pois ao reivindicar uma característica biológica apenas para indivíduos com pele negra, deixa-se uma porta aberta a especulações de que outras características biológicas podem ser exclusivas desses indivíduos.

\footnotetext{
${ }^{13}$ Com esta atitude, podemos estar deixando de diagnosticar a doença em não-negros e não afro-
} descendentes.

Cad. de Pesq. Interdisc. em Ci-s. Hum-s., Florianópolis, v.10, n.97, p. 290-311, jul./dez. 2009 
No caso da hipertensão e do DMNID (que tem como característica principal a resistência à insulina, e não a falta de produção de insulina pelo pâncreas, como ocorre no Diabetes Mellitus Dependente de Insulina), a questão torna-se ainda mais complexa, pois essas doenças sabidamente têm influência de múltiplos fatores.

A incidência de hipertensão parece estar ligada a fatores hereditários, poligênicos, mas que não são determinantes no sentido de desenvolver a doença, pois fatores ambientais (alimentação rica em sódio, idade, sexo, massa corporal) têm sido relacionados ao seu desenvolvimento. Mais ainda, o desenvolvimento da HAS pode ser associado a um ambiente competitivo e estressante que leva a alterações hormonais que, por sua vez, propiciam um aumento da pressão arterial de forma crônica. No caso dos afro-descendentes, a discriminação racial, a falta de oportunidades de emprego e de educação, além de outros fatores que estão presentes em suas vidas gerando ansiedade crônica, podem ser mais importantes no curso dessa doença do que fatores genéticos (FRY, 2005b).

No entanto, a hipótese de que a HAS em negros/afro-descendentes estaria ligada a uma questão genética/racial, ainda é defendida no meio biomédico, embora seja contestada por alguns cientistas (COOPER; KAUFMAN; WARD, 2003; FRYb, 2005; KAUFMAN, 2006, 2008; LEWONTIN, 2006). Um dos argumentos seria a persistência de um gene presente em africanos que os tornou capazes de resistir ao processo de transporte e às más condições de vida relacionadas à escravidão por aumentar a capacidade de reter sódio. No caso da ineficácia dos medicamentos específicos para HAS, que também ocorreria nessas populações, a explicação seria a presença de uma via metabólica, determinada geneticamente, que intervém na degradação dos medicamentos comumente utilizados, alterando sua ação terapêutica (KAUFMAN, 2006). As vias metabólicas possuem um componente genético que, da mesma forma que o traço falciforme, está relacionado a questões ambientais e geográficas (por exemplo, substâncias tóxicas presentes no ambiente determinariam que indivíduos com essas enzimas sobrevivessem melhor do que outros que não a ativassem) e presente em algumas populações mais do que em outras (PENA, 2005). 
O fato de algumas populações africanas apresentarem essa característica no seu metabolismo, mais raramente encontrada em europeus, levou ao desenvolvimento de pesquisas relacionando "raça" e resposta a medicamentos (PETSKO, 2004; SEGHAL, 2004; WOOD, 2001). Mesmo considerando as respostas em "negros" e "brancos" similares em relação ao uso de medicamentos (COOPER; KAUFMAN; WARD, 2003; SEGHAL, 2004), o que já invalidaria esse tipo de abordagem, não se pode descartar o uso desse argumento para abrir um nicho de vendas no mercado farmacológico (COOPER; KAUFMAN; WARD, 2003). Além disso, outros fatores poderiam ser levantados, talvez relacionados à ancestralidade no sentido familiar (de um grupo com certa consanguinidade, e não de uma "raça" incluindo todos os indivíduos de pele negra) (COOPER; KAUFMAN; WARD, 2003; LEWONTIN, 2006; SCHWARTZ, 2001) ou mesmo à falta de delimitação precisa na categorização de quem é "negro" e "branco" (KAPLAN; BENNETT, 2003; PENA, 2005).

Em relação ao DMNID, a tentativa de encontrar genes específicos em função da alta prevalência dessa doença em determinados grupos étnicos com a ajuda da pesquisa atual em genômica também pode ser contestada. Sabe-se que essa é uma doença multifatorial, e está bem estabelecida a sua relação com o aumento de peso, por exemplo, Robyn Mcdermott (1998) fala sobre a questão da busca do "gene econômico"14 (trifty gene) em diversas populações sem que, no entanto, tenha sido encontrado. Cita como exemplo o caso dos aborígines da Austrália, que têm alta prevalência da doença, motivando essa associação de uma característica biológica inata (no caso, o gene econômico) ao grande número de casos de diabetes. No entanto, destaca que outros fatores que ocorrem nesse grupo e que já se mostraram determinantes em outras populações não foram levados em conta. Por exemplo, a baixa disponibilidade proteica intraútero seguida de uma alimentação rica em carboidratos após o nascimento, característica de populações de baixa renda, e a exposição, também itraútero, a altos índices glicêmicos, no caso de mães diabéticas.

\footnotetext{
${ }^{14}$ Trifty gene: seria responsável por um aproveitamento intenso de energia a partir dos alimentos em uma época em que estes eram escassos (MCDERMOTT, 1998). Atualmente, com alimentos mais abundantes, as pessoas portadoras desse gene se tornariam obesas, mesmo que ingerindo quantidades de alimentos que não provocam obesidade em outros indivíduos. Ou seja, uma função que anteriormente teria ajudado na sobrevivência humana, hoje seria deletéria porque estaria tornando as pessoas obesas e diabéticas.
} 
Robert Schwartz (2001), ao referir-se também à busca de uma associação entre DMNID, genética e populações que se encontram culturalmente e geograficamente isoladas, lembra que a alta prevalência nesses grupos pode estar mais relacionada à questão da consanguinidade existente do que a uma questão racial, como gostariam alguns.

Embora existam diferenças genéticas relacionadas à seleção natural em pessoas que habitam determinadas regiões, e que podem ser transmitidas para seus descendentes (por exemplo, a cor da pele ou o desenvolvimento de determinadas vias metabólicas), essas características não parecem ser suficientes para definir uma "raça", no sentido de uma ampla gama de características inatas herdadas.

\section{CONSIDERAÇÕES FINAIS}

É inegável que existe um substrato biológico sobre o qual a vida humana acontece, o corpo biológico, que tem a participação do genoma de cada um. Edoardo Boncinelli (2005) considera que as instruções genéticas contidas em cada célula possuem certo determinismo biológico, pois para que ocorram mudanças no genoma são necessários milhares de anos. Para ele, é preciso haver previsão, oferecida pelo código genético, para o funcionamento do corpo, mas não apenas isso. Essa é a primeira história: o genoma que cada um tem e transmite para seus descendentes. Podemos incluir aqui os genes que nos viabilizam esta ou aquela cor de pele.

A segunda história, mais curta, pois ocorre durante a vida de cada um, está relacionada a como esse genoma, presente em cada célula, vai interagir com o meio ambiente que o cerca - alimentação, poluição, exposição a fatores ambientais e até às interações subjetivas do indivíduo, levando a mudanças no metabolismo de cada um (BONCINELLI, 2005). Como exemplos, poderíamos pensar em mecanismos de regulação neuro-endócrina que provocam a hipertensão em indivíduos que sofrem um stress social contínuo, como as pessoas de pele negra nos Estados Unidos, ou a exposição intraútero à dieta hipoproteica para o DMNID. Essas duas histórias estão 
inter-relacionadas, uma depende da outra, mas a segunda pode ser diferente, dependendo do meio em que o indivíduo (enquanto ser biológico) se encontraria.

A terceira história, que para Boncinelli se junta a essas duas primeiras, seria a história cultural, de marca coletiva, onde cada um de nós é imerso quando nasce e passa a sofrer suas influências. O autor utiliza o exemplo da escrita. A potencialidade genética para ler e escrever é a mesma para um analfabeto hoje e há dez mil anos, mas antes poderíamos prescindir dessa atividade, o que hoje não é mais possível ou, pelo menos, essa é uma ferramenta importante atualmente. Aqui também estão nossos valores, que se perpetuam através de gerações e influenciam as atuais e as que estão por vir.

A interação da história cultural, coletiva, que não pertence a cada indivíduo, mas sim às sociedades humanas, com as histórias biológicas - genética e celular de cada um — vai mostrando seus resultados na vida das populações humanas.

Não é possível delegar todas as responsabilidades dos resultados do que é a vida humana à genética, como pretende a sociobiologia. Essa é uma redução que está diretamente vinculada à "terceira história", aquela construída pela nossa subjetividade e que inclui nossos valores, se quisermos utilizar a sugestão de Boncinelli das "três histórias". Mais ainda, no caso do uso do conceito de "raça", essa redução imprime valor científico a uma categoria que nunca foi comprovada como biológica pela ciência, se utilizarmos os critérios de validação da ciência moderna.

"Raça" não é um conceito objetivo, como gostariam alguns. Em sua elaboração participaram indivíduos com suas opiniões, desejos e ambições políticas. Porém, se pudéssemos considerar que algum dia existiram "raças", na espécie Homo sapiens, biologicamente falando, há muito tempo somos todos "SRD"15, inclusive antes mesmo da época em que o racismo surgiu como ideologia.

\footnotetext{
15 "SRD": "Sem Raça Definida" é um termo utilizado para classificar os animais que não possuem as características fenotípicas de uma "raça" definida. É considerado "SRD" um cão "vira-lata", por exemplo, que possui ancestrais desconhecidos ou que são pertencentes a "raças" diferentes, embora Lewontin destaque que, mesmo para plantas e animais, a classificação em "raças" é uma prática mal definida e idiossincrática.
} 


\section{REFERÊNCIAS}

AGAMBEN, G. Homo Sacer: o poder soberano e a vida nua. Belo Horizonte: Editora da UFMG, 2002.

ARENDT, H. O pensamento racial antes do racismo. In: ARENDT, $H$. As origens do totalitarismo. São Paulo: Cia das Letras, 1989. p.188-214.

BHOPAL, R. Is research into ethnicity and health racist, unsound, or important science? British Medical Journal, v. 314, p.17-51, 1997. Disponível em:

<http://www.bmj.com/cgi/content/full/314/7096/1751>. Acesso em: 08 mar. 2007.

BHOPAL, R. Glossary of terms relating to ethnicity and race: for reflection and debate. Journal of Epidemiology and Community Health, v. 58, p. 441-445, 2004.

BONCINELLI, E. Necessità e contingenza della natura umana. Tradução livre de Selvino Assman. Micromega: almanacco di filosofia, Roma: Gruppo Editoriale L'Espresso, n.4, p.8-27, 2005.

COMAS, J. Los mitos raciales. México: UNESCO, 1950.

COOPER, R. S.; KAUFMAN, J. S.; WARD, R. Race and genomics. New England Journal of Medicine, v. 348, n.12, p.1166-1170, 2003.

DINIZ, D. ; GUEDES, C. Informação genética na mídia impressa: a anemia falciforme em questão. Ciência \& Saúde Coletiva, v.11, n.4, p.1055-1062, 2006. Disponível em: <http://www.scielo.br/pdf/csc/v11n4/32341.pdf>. Acesso em: 17 abr. 2008.

FAGOT-LARGEAULT, A. A pesquisa etiológica: caminhos causais, histórias, influências, mecanismos, ontologia causal. In: RUSSO, M.; CAPONI, S. (Org.). Estudos de filosofia e história das ciências biomédicas. São Paulo: Discurso Editorial, 2006. p.185-199.

FRY, P. H. "Feijoada e soul food" 25 anos depois. In: FRY, P. H. A persistência da raça. Rio de Janeiro: Civilização Brasileira, 2005a. p.147-166.

FRY, P. H. The significance of sickle cell anemia within the context of the Brazilian government's 'racial policies' (1995-2004). História, Ciências, Saúde - Manguinhos. Rio de Janeiro, v.12, n.2, p.347-370, 2005b. Disponível em: $<$ http://www.scielo.br/scielo.php?script=sci arttext\&pid=S010459702005000200007\&lng =en\&nrm=iso>. Acesso em: 04 abr. 2008. 
HACKING, I. O autismo: o nome, o conhecimento, as instituições, os autistas e suas interações. In: RUSSO, M.; CAPONI, S. (Org.). Estudos de filosofia e história das ciências biomédicas. São Paulo: Discurso Editorial, 2006. p.305-320.

HUNT, L. M.; MEGYESI, M. S. The ambiguous meanings of the racial/ethnic categories routinely used in human genetics research. Social Science and Medicine, v. 66, n.2, p.349-361, 2008. Disponível em:

$<$ http://www.sciencedirect.com/science? ob=Mlmg\& imagekey=B6VBF-4R05VC5-1$1 \&$ cdi $=5925 \&$ user $=687353 \&$ orig $=$ browse \& coverDate $=01 \% 2 \mathrm{~F} 31 \% 2 \mathrm{~F} 2008 \&$ sk $=999$ 339997\&view=c\&wchp=dGLbVtbzSkWz\&md5=3f8bf27f0015f8105f08c9e3c04526bc\&ie =/sdarticle.pdf $>$. Acesso em: 28 fev. 2008.

KAPLAN, J. B.; BENNETT, T. Use of race and ethnicity in biomedical publication. The Journal of the American Medical Association, v. 289, p. 2709-2716, 2003. Disponível em: <http://jama.ama-assn.org/cgi/reprint/289/20/2709>. Acesso em: 23 fev. 2007.

KAUFMAN, J. S. The anatomy of a medical myth. Social Science Research Council, jun. 2006. Disponível em: <http://raceandgenomics.ssrc.org/Kaufman/>. Acesso em: 27 out. 2007.

KAUFMAN, J. S. Epidemiologic analysis of racial/ethnic disparities: some fundamental issues and a cautionary example. Social Science \& Medicine, v. 66, n.8, p.1659-1669, abr. 2008.

KLINEBERG, O. Race et psychologie. Paris: UNESCO, 1951.

LAGUARDIA, J. Raça, genética e hipertensão: nova genética ou velha eugenia? História,Ciências, Saúde - Manguinhos, Rio de Janeiro, v.12, n.2, 2005. Disponível em: <http://www.scielo.br/pdf/hcsm/v12n2/07.pdf> Acesso em: 04 abr. 2008.

LAGUARDIA, J. Race and epidemiology: strategies to build on biological differences. Ciência \& Saúde Coletiva, Rio de Janeiro, v.12, n.1, p.253-261, 2007. Disponível em: $<$ http://www.scielo.br/scielo.php?script=sci arttext\&pid=S141381232007000100029\&lng=en\&nrm=iso>. Acesso em: 04 abr. 2008.

LEFEBVRE, G. 1789: o surgimento da Revolução Francesa. Rio de Janeiro: Paz e Terra, 1989.

LEWONTIN, R. C. No está en los genes: racismo, genética e ideologia. Barcelona: Romany/Valls S.A., 2003.

LEWONTIN, R. C. Confusions about human races. Social Science Research Council, jun. 2006. Disponível em: <http://raceandgenomics.ssrc.org/Lewontin/>. Acesso em: 16 fev. 2008. 
MAIO, M. C.; MONTEIRO, S. In times of racialization: the case of the 'health of the black population' in Brazil. História, Ciências, Saúde - Manguinhos, Rio de Janeiro, v.12, n.2, p.419-446, 2005. Disponível em:

$<$ http://www.scielo.br/scielo.php?script=sci arttext\&pid=S010459702005000200010\&lng =en\&nrm=iso>. Acesso em: 08 mar. 2008.

MCDERMOTT, R. Ethics, epidemiology and the thrifty gene: biological determinism as a health hazard. Social Science \& Medicine, v.47, n.9, p.1189-1195, nov. 1998.

Disponível em:

$<$ http://www.sciencedirect.com/science? ob=Mlmg\& imagekey=B6VBF-3WBWYBH-8 $1 \&$ cdi $=5925 \&$ user $=687353 \&$ orig $=$ search \& coverDate $=11 \% 2 \mathrm{~F} 30 \% 2 \mathrm{~F} 1998 \&$ sk $=999$ 529990\&view=c\&wchp=dGLbVtbzSkzS\&md5=d2eef89155309c51128d8d94fb3c8d66\&i e=/sdarticle.pdf>. Acesso em: 03 abr. 2008.

PENA, S. D. J. Reasons for banishing the concept of race from Brazilian medicine. História, Ciências, Saúde - Manguinhos, Rio de Janeiro, v.12, n.2, p.321-346, 2005. Disponível em: <http://www.scielo.br/scielo.php?script=sci arttext\&pid=S010459702005000200006\&lng =en\&nrm=iso>. Acesso em: 09 mar. 2007.

PETSKO, G. A. Color blind. Genome Biology, v.5, n.12, comment 119, 2004. Disponível em: $<$ http://www.pubmedcentral.nih.gov/picrender.fcgi?artid=545786\&blobtype=pdf> . Acesso em: 07 abr. 2008.

SAHLINS, M. The use and abuse of biology: an anthropological critique of sociobiology. Michigan: Michigan Press, 1976.

SAHLINS, M. O "pessimismo sentimental" e a experiência etnográfica: por que a cultura não é um "objeto" em via de extinção (parte II). Mana, v.3, n.2, p.103-150, 1997. Disponível em:

<http://www.scielo.br/scielo.php?script=sci arttext\&pid=S010493131997000100002\&lng =en\&nrm=iso>. Acesso em: 05 mar. 2007.

SCHWARTZ, R. S. Racial profiling in medical research. New England Journal of Medicine, v.344, n.18, p. 1392-1393, maio 2001. Disponível em: <http://ovidsp.tx.ovid.com/spa/ovidweb.cgi>. Acesso em: 08 mar. 2008.

SEGHAL, A. R. Overlap between whites and blacks in response to antihypertensive drugs. Hypertension, v.43, p.566-572, 2004. Disponível em:

<http://hyper.ahajournals.org/cgi/reprint/43/3/566>. Acesso em: 29 mar. 2008. 
WIKIPEDIA. Ottmar Freiherr von Verschuer. Disponível em: $<$ http://en.wikipedia.org/wiki/Otmar von Verschuer>. Acesso em: 08 mar. 2007a.

WIKIPEDIA. Eugen Fischer. Disponível em:

$<$ http://en.wikipedia.org/wiki/Eugen Fischer>. Acesso em: 08 mar. 2007b.

WOOD, A. J. J. Racial differences in the response to drugs: pointers to genetic differences. New England Journal of Medicine , v.344, n.18, p.1393-1396, maio 2001.

Ensaio:

Recebido em: 24/10/2009

Aceito em: 08/11/2009 